\title{
EFFECTIVENESS OF TOTAL PHYSICAL RESPONSE
}

\author{
Jai Prakash Singh \\ Department of English Education
}

\begin{abstract}
The present article is an attempt to overview Total Physical Response as a method of language teaching and to show its implications in English language classroom, particularly in vocabulary teaching at elementary grades.
\end{abstract}

\section{Keywords}

Total Physical Response(TPR), lesson plan, intervention, target langauge, wordassociation

\section{Introduction}

Total Physical Response (TPR) is a language teaching method which establishes a link between speech, a primary mode of language and action. The mode of teaching language here is a motoractivity. TPR reflectsagrammarbased view of language. It was James Asher, an American Professor of Psychology who brought the idea of TPR in 196os. He states that "most of the grammatical structures of the target language and hundreds of vocabulary items can be learned from the skillful use of the imperative by instructor" (1977, p.4, cited in Richards \& Rodgers, 2002, p.73). There are three processes central to TPR:

a. Children develop listening competence before they develop the ability to speak. At the early stages of first language acquisition, they can understand complex utterances that they cannot spontaneously produce or imitate. b. Children'sabilityin listening comprehension is acquired because they are required to respond physically to spoken language in the form of parental commands.

c.Once the foundation in listening comprehension has been established, speech evolves naturally and effortlessly out of it.

Asher views there are three elements that explain the success of TPR. First is that it is aptitude free. In other words, this is effective for everyone regardless of bright and less bright students. It is TPR that creates an impression amongst all students that they all are 'A' class students. The second element of TPR is that it works with both children and adults. Finally, TPR shows a radical departure from the audiolingual practice. Asher also recommends that beginners should be allowed a silent period in which they learn to recognize a large number of words without being expected to say them. 


\section{TPR in English language classroom}

The teacher begins this by uttering a simple command such as "walk to the window" or "Raise your hand" demonstrating or having a helper student act out, addressing first to the entire class, then to small groups and finally to individuals. When basic verbs and nouns have become familiar, TPR can be practiced to teach many things. Students are required to carry out the instructions physically performing the activities. They are given supportive classroom environment. There is no doubt to the fact that activities become motivating and create a lot of fun and students enjoy. After the teacher has practiced these commands with the students several times, the teacher remains seated and the volunteers carry out the commands by themselves. If students are confused, the teacher repeats the commands. Again the teacher introduces new sets of commands. In TPR, the teacher plays the role of director of student behavior but the students are imitators of his nonverbal model (Larsen-Freeman, 2004).

Students in Total Physical Response are supposed to play the roles of listeners and performers. They listen to the teacher attentively and respond physically to command given. They are also expected to recognize and respond to novel combination of their own. Learners monitor and evaluate their own progress. The teacher is supposed to play an active and direct role. He/She is supposed to decide what to teach, who models and presents the new materials and who selects supporting materials for classroom use. A detailed lesson plan is recommended to follow TPR in classroom. It is always good to write the exact utterances teacher will be using in the classrooms. The teacher has the responsibility of providing the best kind of exposure so that students can internalize the basic rules of the target language. He/ She also controls the language inputs. $\mathrm{He} /$ she is also supposed to refrain from too much correction in the early stages and should not interrupt even if errors are committed. As time goes on, more teacher intervention is expected as students' speech is likely to become awkward. The role of a student in a TPR classroom is similar to that of the teacher. In order for the student to remain engaged, they must pay attention and participate in class discussions and the main story for the day. Almost always the students continue to be engaged in the lesson because the stories are fun and require student participation. Most students anticipate when they are called on by the teacher. The students must remain on their toes because the teacher may call on them at any particular time throughout the lesson. Calling on the students is a great way for students to participate in the lesson and practice the vocabulary through repetition. Using TPR in the classroom attendance is important because the method requires observation of the teacher for their pronunciation of the words and for the word associations. The word associations are the gestures the student or teacher creates in order to remember the specific vocabulary. For example, a great way for students to learn general commands such as sit and stand up, the teacher uses his or her hands to demonstrate a tiny person. This person is used to show how he/she sits or stands. When the teacher says sentence (sit down) then the students must show their little person sitting down on the side of their other hand. This technique keeps the students engaged because they do not know what is going to happen next and it helps students to remember the word because of repetition. If a student misses a few days of school the student may quickly fall behind depending on the enthusiasm of the student when they return. This method does not require homework because it is hard when students are at home completing homework that they do not understand. The students' job is limited in the classroom.

\section{Studies on TPR}

Patrick et al. (2008) studied the effects of Total Physical Response through Storytelling and the Traditional Teaching styles of a foreign language in a selected high school in Northeast Tennessee. The results indicated a significant difference between TPR and the traditional style on the overall performance of 


\section{J. P. Singh}

the students. Similarly, significant difference was found between TPR and traditional style on vocabulary. The students taught using TPR performed significantly higher than the students taught using the traditional method.

Sitaula (2008) assessed the effectiveness of Total Physical Response (TPR) method in teaching imperatives at primary level. The effectiveness of the method was judged in terms of listening and speaking skills. It was found that young children can communicate in the foreign language if the teacher motivates them with activities that lead them to use the target language. This study also reflects that in TPR students' motivation level is high and anxiety level is low. The study conclude that TPR is a valuable asset to teach a new language for the beginners.

Similarly, Yadav(2010) carried out an experimental research on the effectiveness of Total Physical Response and it was found very effective in teaching vocabulary while compared to traditional ways of teaching. The experimental group out-performed control group in the post test. It was also found that total physical response had greater influence on the performance of the students in both listening and speaking skills. Motivation was extremely high as students watched and listened and performed actions. It was observed that students also enjoyed getting up out of benches and moving around and performing. Students also claimed that they were subconsciously repeating the vocabulary in different patterns as they were being said.

\section{Conclusion}

The studies reveal that Total physical response (TPR) is a very effective tool to teach English language, especially vocabulary. Most studies

\section{The Author}

confirm that the students taught using TPR perform significantly better than the students taught using the traditional method. TPR also helps in developing listening and speaking skills as the students are required to listen to the commands and act accordingly. Therefore, it is very important that TPR is used EFL classroom at primary level to enhance the listening and speaking skills and to enrich their vocabulary.

\section{References}

Asher, J. (1977). Learning another language through actions: the complete teacher's guidebook. Los Gatos, Calif: Sky Oaks Publications.

Larsen-Freeman, D. (2004). Techniques and principles in language teaching. New Delhi: Oxford University Press.

Richards, J.C. and Rodgers, T.S.(2006). Approaches, methods and techniques in language teaching. New York: CUP.

Sitauala, G.(2008). Act, don't explain: Total Physical Response at work. Journal of NELTA. 13(1-2), 80-86.

Yadav, D. P.(2010). Effectiveness of TPR in teaching vocabulary. Unpublished thesis. Tribhuvan University.

Patrick N. Kariuki K and Bush E. D. (2008). The effects of Total Physical Response by storytelling and the traditional teaching styles of a freign language in a selected High School. A paper presented at the Annual Conference of the Mid. South Educational Research Association Milligan College Knoxville, Tennessee, November 5-7,

Jai Prakash Singh is an Associate Professor of English Education, Thakur Ram Multiple Campus, Birgunj where he has been teaching for the last three decades. He teaches courses such as Pragmatics and Discourse Analysis, Research Methodology in Language Education, Second Language Acquistion(SLA) and Sociolinguistics. He is the Immediate Past Chair of NELTA Birgunj. He has published several articles in ELT Today, journal of NELTA, Birgunj. 